\title{
The Risk Factors of Obesity Among Elderly in Sintang, Indonesia
}

\author{
Abil Rudi ${ }^{*}$, Novin Yetiani ${ }^{2}$ \\ ${ }^{1,2}$ Kapuas Raya College of Health Sciences, Sintang, West Kalimantan, Indonesia \\ *Corresponding author: \\ Email: abilrudistg@Gmail.com
}

\begin{abstract}
.
Body Mass Index problem is becoming a double burden in Indonesia, including among older people. Nowadays, the elderly face a high index of BMI due to some risk factors and it is leading to other noncommunicable diseases. This research aimed to examine the correlation between some determinants and obesity among older people in Sintang Regency, West Kalimantan. 358 elderly aged 46 to 65 years participated in this study selected by the total sampling method. The independent variables in this study were knowledge, activity, food intake, sex, attitude, age, the history of obesity, and obesity breeds, type contraception, and the duration of sleep. The multivariate analysis was found that knowledge, activity, food intake, age, and duration of sleep were significantly associated with obesity among the elderly. The preventive and promotive approach is needed to treat the obesity prevalence.
\end{abstract}

Keywords: Obesity, Elderly

\section{INTRODUCTION}

The aging population is the latest phenomenon in the world, including Indonesia. Older people could be a concern in terms of their health status, especially the high risk of non-communicable diseases. Globally, obesity is a common public health problem which showed by the WHO in 2016, 2.3 billion adults including the elderly gain obesity. Obesity is the condition when the accumulation of fat is excess which can be defined by BMI (Body Mass Index) measurement [1]. Obesity is influenced by a combination of factors including individual factors such as behavior (dietary patterns, physical activity, inactivity, medication use, and other exposures) and genetics [2].

West Kalimantan Province reported 8.6\% of adults and the elderly were obese in 2016 [3]. Particularly, in Sintang Regency, the Obesity case revealed $10.3 \%$ in 2016 which quite higher than provincial data [4]. The prevalence of obesity in this area remains high and might become a risk to other non-communicable diseases like cardiovascular disease [5]. The effect of obesity might be more serious in a particular age like older people, which can be the risk of cardiovascular, stroke, diabetes mellitus type 2, hypertension, osteoarthritis [6].

The primary survey was conducted and revealed that $52.26 \%$ of the elderly gained the overweight and obese. This study was concerning knowledge, activity, food intake, and the history of obesity. This study aimed to examine the potential contributing factors and the dependent variable.

\section{METHODS}

This research retrieved 358 respondents in Tempunak, Sintang. Regency which was selected by total sampling. The dependent variable was measured by BMI formula (weight in $\mathrm{kg} /$ height 2). The knowledge was examined by the questionnaire. Specifically, the physical activity was measured by the IPAQ-short form, then the food intake was measured by the food frequency questionnaire (FFQ). The data was analyzed by statistic software such as univariate, bivariate by using Chi-Square and multivariate by using Double Logistic Regression. The confidence interval is defined as $95 \%(\alpha=0,05)$ and the odds ratio was used to define the risk.

\section{RESULTS AND DISCUSSION}

\section{The Univariate Results}

The univariate analysis was done to describe each variable. Table 1 below describes that more than half of the respondents were obese in type 1 . In terms of knowledge, more than half of them did not have enough knowledge related to obesity. The physical activity was also found that more than half of them did 
not have sufficient physical activity. Regarding food intake, the majority of the respondents did not have adequate food intake. The majority of the respondents were female. About 55\% of them did not practice a good attitude, and mostly they were in the aged range 46-55 years. Most of them also had a history of obesity and genetic factor was taking the large part. In terms of contraception, most of them did not use any contraception method and they mostly had less than 7 hours of sleep duration.

Table 1. Description of each variable

\begin{tabular}{|c|c|c|}
\hline Variable & $\mathbf{n}$ & Percentage \\
\hline \multicolumn{3}{|l|}{ Obesity } \\
\hline Obesitas Type 1 & 182 & $50,8 \%$ \\
\hline Obesitas Type 2 & 176 & $49,2 \%$ \\
\hline \multicolumn{3}{|l|}{ Knowledge } \\
\hline Good & 169 & $47.2 \%$ \\
\hline Not good & 189 & $52.8 \%$ \\
\hline \multicolumn{3}{|l|}{ Physical activity } \\
\hline Good & 176 & $49.2 \%$ \\
\hline Not good & 182 & $50.8 \%$ \\
\hline \multicolumn{3}{|l|}{ Food intake } \\
\hline Good & 170 & $47.5 \%$ \\
\hline Not good & 188 & $52.5 \%$ \\
\hline \multicolumn{3}{|l|}{ Sex } \\
\hline Male & 157 & $43.9 \%$ \\
\hline Female & 201 & $56.1 \%$ \\
\hline \multicolumn{3}{|l|}{ Attitude } \\
\hline Good & 161 & $45 \%$ \\
\hline Not good & 197 & $55 \%$ \\
\hline \multicolumn{3}{|l|}{ Age } \\
\hline Early elderly (aged 46-55) & 181 & $50.6 \%$ \\
\hline Late elderly (aged 56-65) & 177 & $49.4 \%$ \\
\hline \multicolumn{3}{|l|}{ History of obesity } \\
\hline Yes & 238 & $66.5 \%$ \\
\hline No & 120 & $33.5 \%$ \\
\hline \multicolumn{3}{|l|}{ Genetic } \\
\hline Yes & 194 & $54.2 \%$ \\
\hline No & 164 & $45.8 \%$ \\
\hline \multicolumn{3}{|l|}{ Use contraception } \\
\hline Yes & 157 & $43.9 \%$ \\
\hline No & 201 & $56.1 \%$ \\
\hline \multicolumn{3}{|l|}{ Sleep duration } \\
\hline More than 7 hours & 157 & $43.9 \%$ \\
\hline Less than 7 hours & 201 & $56.1 \%$ \\
\hline
\end{tabular}

\section{The Bivariate analysis}

The Chi-square analysis in this study was present in table 2 below. The results were revealed that knowledge and sleep duration significantly had a mid relationship with obesity. For other variables, it was also found that physical activity, food intake, sex, attitude, age, history of obesity, genetic, and use of contraception significantly had a weak relationship with obesity. Furthermore, the attitude did not have any association with obesity.

Table 2. The relationship between each variable and the obesity

\begin{tabular}{|c|c|c|c|c|}
\hline \multirow{2}{*}{ Variable } & \multicolumn{2}{|l|}{ Obesity } & \multirow{2}{*}{ P-value } & \multirow{2}{*}{$\begin{array}{l}\text { OR } \\
(95 \% \text { CI) }\end{array}$} \\
\hline & Type 1 & Type 2 & & \\
\hline \multicolumn{5}{|c|}{ Knowledge } \\
\hline Good & $95(50.3 \%)$ & $94(49.7 \%)$ & \multirow{2}{*}{$0.002^{* *}$} & \multirow{2}{*}{$\begin{array}{l}4.953 \\
(2.629-5.443)\end{array}$} \\
\hline Not good & $87(51.5 \%)$ & $82(48.5 \%)$ & & \\
\hline \multicolumn{5}{|c|}{ Physical activity } \\
\hline Good & $102(56.0 \%)$ & $80(44.0 \%)$ & \multirow{2}{*}{$0.048^{*}$} & \multirow{2}{*}{$\begin{array}{l}1.530 \\
(1.009-2.321)\end{array}$} \\
\hline Not good & $80(45.5 \%)$ & $96(54.5 \%)$ & & \\
\hline \multicolumn{5}{|c|}{ Food intake } \\
\hline Good & $92(48.9 \%)$ & $96(51.1 \%)$ & $0.015^{*}$ & 1.852 \\
\hline
\end{tabular}

http://ijstm.inarah.co.id 


\begin{tabular}{|c|c|c|c|c|}
\hline Not good & $90(52.9 \%)$ & $80(47.1 \%)$ & & $(2.562-3.290)$ \\
\hline $\begin{array}{l}\text { Sex } \\
\text { Male } \\
\text { Female }\end{array}$ & $\begin{array}{l}68(43.3 \%) \\
114(56.7 \%)\end{array}$ & $\begin{array}{l}89(56.7 \%) \\
87(43.3 \%)\end{array}$ & $0.012^{*}$ & $\begin{array}{l}3.583 \\
(2.383-4.889)\end{array}$ \\
\hline $\begin{array}{l}\text { Attitude } \\
\text { Good } \\
\text { Not good } \\
\end{array}$ & $\begin{array}{l}86(53.4 \%) \\
96(48.7 \%) \\
\end{array}$ & $\begin{array}{l}75(46.6 \%) \\
101(51.3 \%)\end{array}$ & 0.078 & $\begin{array}{l}1.206 \\
(1.795-2.831)\end{array}$ \\
\hline $\begin{array}{l}\text { Age } \\
\text { Early Elderly (aged 46-55) } \\
\text { Late Elderly (aged 56-65) }\end{array}$ & $\begin{array}{l}91(50.3 \%) \\
91(51.4 \%)\end{array}$ & $\begin{array}{l}90(49.7 \%) \\
86(48.6 \%)\end{array}$ & $0.030^{*}$ & $\begin{array}{l}5.956 \\
(3.631-6.446)\end{array}$ \\
\hline $\begin{array}{l}\text { History of Obesity } \\
\text { Yes } \\
\text { No }\end{array}$ & $\begin{array}{l}118(49.6 \%) \\
64(53.3 \%)\end{array}$ & $\begin{array}{l}120(50.4 \%) \\
56(46.7 \%)\end{array}$ & $0.020^{*}$ & $\begin{array}{l}3.860 \\
(2.554-4.335)\end{array}$ \\
\hline $\begin{array}{l}\text { Genetic } \\
\text { Yes } \\
\text { No }\end{array}$ & $\begin{array}{l}106(54.6 \%) \\
76(46.3 \%)\end{array}$ & $\begin{array}{l}88(45.4 \%) \\
88(53.7 \%)\end{array}$ & $0.018^{*}$ & $\begin{array}{l}5.395 \\
(3.179-6.043)\end{array}$ \\
\hline $\begin{array}{l}\text { Use contraception } \\
\text { Yes } \\
\text { No }\end{array}$ & $\begin{array}{l}114(56.7 \%) \\
68(43.3 \%)\end{array}$ & $\begin{array}{l}87(43.3 \%) \\
89(56.7 \%)\end{array}$ & $0.016^{*}$ & $\begin{array}{l}2.583 \\
(1.383-3.089)\end{array}$ \\
\hline $\begin{array}{l}\text { Sleep duration } \\
\text { More than } 7 \text { hours } \\
\text { Less than } 7 \text { hours }\end{array}$ & $\begin{array}{l}68(43.3 \%) \\
114(56.7 \%)\end{array}$ & $\begin{array}{l}89(56.7 \%) \\
87(43.3 \%)\end{array}$ & $0.008^{* *}$ & $\begin{array}{l}6.337 \\
(4.812-7.335)\end{array}$ \\
\hline
\end{tabular}

\section{The Multivariate analysis}

The multivariate analysis in this study took five variables based on bivariate results. They were knowledge, physical activity, food intake, age, and sleep duration. After adjusted with other independent variables, it was found that knowledge, physical activity, and food intake had a mid relationship with obesity. Particularly, those who had insufficient knowledge were 7.6 times more likely to be obese $(\mathrm{p}=$ 0.002, OR 7.6, CI 95\% 5.219-8.613), for those who did not practice enough physical activity were 6.9 times more likely to be obese $(\mathrm{p}=0.006$, OR 6.9, CI 95\% 5.435-7.039), and for those who did not have an adequate intake of food was 8.2 times more likely to be obese $(\mathrm{p}=0.008$, OR $8.2 \%$, CI 95\% 6.36410.054). In term of weak relationship, it was found that those aged 46 to 55 years were 6.7 times more likely to be obese $(p=0.012$, OR 6.7 , CI 95\% 5.993-8.335) and for those who had sleep duration less than 7 hours were 5.2 times more likely to be obese $(\mathrm{p}=0.014$, OR 5.2, CI 95\% 3.983-6.354).

Table 3. The logistic regression result of multivariate analysis

\begin{tabular}{llll}
\hline Variable & OR & 95\% CI & P-value \\
\hline Knowledge & 7.623 & $5.219-8.613$ & $0.002^{* *}$ \\
Physical activity & 6.993 & $5.435-7.039$ & $0.006^{* *}$ \\
Food intake & 8.256 & $6.364-10.054$ & $0.008^{* *}$ \\
Age & 6.776 & $5.993-8.335$ & $0.012^{*}$ \\
Sleep duration & 5.256 & $3.983-6.354$ & $0.014^{*}$ \\
\hline
\end{tabular}

\section{Discussion}

The literature review article observed the elderly in Malaysia was found three contributory factors for obesity such as socio-demographic factors, medical history, and dietary factors, and environmental factors [7]. These results supported the finding of this study which found that some sociodemographic and dietary factors were significantly associated with obesity. One study in Padang, West Sumatera Province, Indonesia did not find the same result as this study which revealed the negative association between knowledge and obesity [8].

Physical activity in this study was significantly associated with obesity. Supporting this study, the previous study in Brazil and Padang Indonesia also found that lower in physical activity in the leisure time had an association with obesity [9]. Additionally, one study in Sweden also found that physical activity and mobile activity was found a significant association with [10].

In terms of food intake, this study found that food intake was significantly associated with obesity. One study in Sharpeville, South Africa brought specific nutrients of food, namely Fe. The result revealed differently with this current study which found the Fe status was not significantly associated with obesity [11]. Indonesia is a country with rice as a staple food. The study in China revealed that the rice staple pattern was associated with abdominal obesity in men elderly, but not in women [12]. It describes that 
rice intake could be the risk of obesity. A study in Korea also supports this current study, particularly a concern in protein intake, that study found the lower protein intake the higher risk for being obese [13]. Studies in Sweden and Brazil found that the intake of fruit and vegetable was associated with obesity [14]. On the other hand, the study conducted in Purwosari Indonesia did not find the relationship between food intake especially for energy, carbohydrate, and far with obesity among older people [15].

The study in Brazil also found the same result as this study, which found age was inversely associated with abdominal obesity [9]. The prevalence of obesity based on a study in Sweden and Padang Indonesia found that aged 65-75 years were the higher risk and it decreases after aged 75 years [10]. One study in Brazil also found that aged 60-79 years was a high risk of being obese [16].

In the line with this study, a study among the Korean elderly also found that short sleep duration (less than 6 hours) was the risk of being obese [17]. Doo also found that the risk of being obese tended to be higher with those who had a short sleep duration compared with those who had a proper sleep duration [18]. Opposite with current findings, the study in Greece found a negative association between sleep quality and obesity [19].

The study conducted in Brazil found different risk factors of obesity which revealed that having hypertension, dyslipidemia, and the female gender was a strong association with overweight and obesity [20]. In the line with another study in China, overweight was associated with a decreased risk of cognitive impairment, and abdominal obesity was associated with an increased risk of cognitive impairment (sociodemographic, lifestyle, comorbid factors) [21]. Another study in Brazil found that sex, marital status, the presence of disease, and smoking behavior were significantly associated with BMI and waist circumference [22]. These results did not support this current study. Another result was shown by a study in Padang Indonesia that found a significant association between the history of obesity and the prevalence of obesity among the elderly [8]. The prevalence of obesity was affected by the loss of muscle mass regarding the study in Salatiga Indonesia [23].

Additionally, obesity is also leading to non-communicable diseases as found in the study conducted in Indonesia that found obesity as a risk factor for diabetes mellitus [24].

\section{CONCLUSION}

The strong predictors for being obese among the elderly were knowledge, physical activity, and food intake. Additionally, age and sleep duration had a weak association with obesity. Familial factors are associated with aderly obesity, dietary intake, physical activity and weight control behaviors. The role of family members is needed to prevent and treat obesity among older people.

\section{ACKNOWLEDGMENTS}

The authors are grateful to the elderly in Sintang district who have been willing to become respondents. We also thank the Sintang District Health Office for their support and for their permission to collect data on elderly people.

\section{REFERENCES}

[1] WHO. Obesity. Retrieved from https://www.who.int/topics/obesity/en/. 2019.

[2] CDC. Overweight and Obesity. Adult Obesity Cuases and Consequences. 2020.

[3] Dinkes Kalbar. Profil Dinas Kesehatan Provinsi Kalimantan Barat. 2017.

[4] Dinkes Sintang. Profil Dinas Kesehatan Kabupaten Sintang. 2017.

[5] Sjarif, D. Anak gemuk, apakah sehat? Jakarta : Devisi anak dan penyakit metabolic. Jakarta. 2004.

[6] Nurmalina, R., \& Valley, B. Pencegahan dan manajemen obesitas. Jakarta: PT Elex Media Komputindo Kelompok Gramedia. 2011.

[7] Ismail, N. R., \& Hamid, N. A. Contributory Factors for Obesity in Elderly: Review of the Literature. Journal of The Indian Academy of Geriatrics. 2009. 15(3), pp. 138-145.

[8] Azhari, R.. Faktor yang Berhubungan dengan Kejadian Obesitas pada Lansia di Wilayah Kerja Puskesmas Nanggalo Kota Padang Tahun 2016. 2016. Universitas Andalas.

[9] Costa, Caroline dos Santos Schneider, Bruna Celestino Cesar, J. A. General and abdominal obesity among the elderly from Southern Brazil : results of the HOW ARE YOU DOING ? (COMO VAI ?) study. Ciencia \& Saude Coletiva. 2016. 21 (11), pp. 3585-3597. https://doi.org/10.1590/1413-812320152111.02492016.

[10] Asp, M., Simonsson, B., Larm, P., \& Molarius, A. Physical mobility, physical activity, and obesity among elderly: findings from a large population-based Swedish survey. Public Health. 2017. pp. 147, 84-91. https://doi.org/10.1016/j.puhe.2017.01.032. 
[11] Oldewage-theron, W. H., Egal, A. A., \& Grobler, C. J. Is obesity associated with iron status in the elderly ? A case study from Sharpeville, South Africa. Public Health Nutrition. 2014. 18(3), pp. 521-529. https://doi.org/10.1017/S1368980014000251.

[12] Ya-Qun, Y., Fan, L., Pai, M., Jie, Y., Min, W., Shu-Guang, L., \& Bo, C. Gender Difference on the Association between Middle-Aged and Elderly Populations. Nutrients. 2016. 8(448), nu8080448. https://doi.org/10.3390/nu8080448.

[13] Lee, M. H., \& Park, Y. Prevalence and Factors Related to Sarcopenic Obesity among Community-dwelling Elderly Women. Journal of Korean Biological Nursing Science. 2017. 19 (1), pp. 30-37.

[14] Aparecida, E., Vieira, L. L., Jardim, T. V., \& Souza, J. D. De. Original Article Obesity and its Association with Food Consumption, Diabetes Mellitus, and Acute Myocardial Infarction in the Elderly. Sociedade Brasileira De Cardiologia. 2016. 107 (6), pp. 509-517. https://doi.org/10.5935/abc.20160182.

[15] Rahayu, N. T. Hubungan asupan energi, karbohidrat dan lemak dengan status obesitas pada lansia di posyandu lansia wedra utama Purwosari. Universitas Muhammadiyah Surakarta. 2017.

[16] Aparecida, E., Vieira, L. L., Jardim, T. V., \& Souza, J. D. De. Original Article Obesity and its Association with Food Consumption, Diabetes Mellitus, and Acute Myocardial Infarction in the Elderly. Sociedade Brasileira De Cardiologia. 2016. 107 (6), pp. 509-517. https://doi.org/10.5935/abc.20160182.

[17] Doo, M., \& Kim, Y. The Consumption of Dietary Antioxidant Vitamins Modifies the Risk of Obesity among Korean Men with Short Sleep Duration. Nutrients. 2017.9 (780), 8-11. https://doi.org/10.3390/nu9070780.

[18] Doo, M. The Association between Sleep Duration and 25-Hydroxyvitamin D Concentration with Obesity in an Elderly Korean Population: A Cross-Sectional Study. Nutrients. 2018. 10 (575), nu10050575. https://doi.org/10.3390/nu10050575.

[19] Mamalaki, E., Tsapanou, A., Anastasiou, C. A., Kosmidis, M. H., \& Dardiotis, E. Associations between sleep and obesity indices in older adults: results from the HELIAD study. Aging Clinical and Experimental Research. 2019.31 (11), pp. 1645-1650. https://doi.org/10.1007/s40520-018-01113-2.

[20] Cristina, C., \& Ferreira, D. (2018). Nutritional Status and Associated Factors in the elderly: Evidence Based on Telephone Survey. 2 Rev Bras Promoç Saúde, Fortaleza. 2018. 31 (1), 1-10.

[21] Hou, Q., Guan, Y., Yu, W., Liu, X., Wu, L., Xiao, M., \& Lu, Y. Associations between obesity and cognitive impairment in the Chinese elderly: an observational study. Clinical Interventions in Aging. 2019. 14, pp. 367-374.

[22] Andrade, T. B. De, Junior, A. de F. C., Kitoko, P. M., Batista, jose E. M., \& Andrade, T. B. de. Prevalence of overweight and obesity in elderly people from Vitória-ES, Brazil. Ciencia \& Saude Coletiva. 2012. 17 (3), pp. 749-757.

[23] Nugroho, K. P., Kurniasari, M. D., \& Noviani, T. Gambaran Pola Makan Sebagai Penyebab Kejadian Penyakit Tidak Menular (Diabetes Mellitus, Obesitas, dan Hipertensi) di Wilayah Kerja Puskesmas Cebongan, Kota Salatiga. Jurnal Kesehatan Kusuma Husada. 2019. pp. 15-23.

[24] Nugroho, P. S., Tianingrum, N. A., Sunarti, S., Rachman, A., \& Saptono, D. Predictor Risk of Diabetes Mellitus in Indonesia, based on National Health Survey. Malaysian Journal of Medicine and Health Sciences. 2020. 16 (11), pp. 126-130. 